\title{
Effect of Integrated Nutrient Management on Yield Attributes, Yield and Economics of Sorghum Based Intercropping Systems
}

\author{
G. J. Bhagat ${ }^{1}$, D. G. Giri ${ }^{2}$, P. C. Pagar ${ }^{2}$ and S. S. Hadole ${ }^{3}$ \\ ${ }^{1}$ College of Agriculture, Dr.PDKV, Akola, India \\ ${ }^{2}$ Department of Agronomy, Dr.PDKV, Akola, India \\ ${ }^{3}$ Department of SSAC, Dr PDKV, Akola, India \\ *Corresponding author
}

\section{A B S T R A C T}

\begin{tabular}{|l|}
\hline Ke y w or d s \\
INM, Sorghum, \\
intercropping \\
system
\end{tabular}

\begin{abstract}
A field experiment was conducted on influence of integrated nutrient management on growth, yield and economics of sorghum based legume intercropping systems was conducted in Kharif season at the Farm of Department of Agronomy, Dr. PDKV, Akola. The experiment was conducted in split plot design having eight treatments of intercropping systems in main plots and three treatments of integrated nutrient management in sub plots replicated three times. Results of experiment revealed that sorghum+ pigeonpea intercropping system recorded significantly highest yield attributes of sorghum, sorghum grain equivalent yield, gross monetary returns (GMR), net monetary returns (NMR) and B:C ratio of system over other treatments. Grain, straw and biological yield per hectare of sorghum were highest with sole sorghum which was significantly superior over other treatments. However, Sorghum+ pigeonpea intercropping system and sole sorghum being par recorded maximum total grain productivity over other treatments. Application of $50 \% \mathrm{RDF}$ with 5 t/ha FYM and biofertilizers recorded significantly highest yield attributes, grain, straw and biological yield per hectare of sorghum and highest sorghum grain equivalent yield, total grain productivity, gross monetary returns (GMR) and net monetary returns (NMR)of system over other treatments. However, $\mathrm{B}: \mathrm{C}$ ratio was maximum with application of $\mathrm{RDF}$ for respective crops $\left(\mathrm{F}_{1}\right)$ and application of $50 \%$ RDF with 5 t/ha FYM and biofertilizers $\left(\mathrm{F}_{3}\right)$.
\end{abstract}

\section{Introduction}

Sorghum (Sorghum bicolor (L.) Moench) is the third most important cereal crop in India and the fourth most important of the world. It is one of the major staple food crops of millions of people in semi-arid tropics. It is considered as the "king of millets" in India, sorghum is popularly grown as main source of food (grain) and fodder by poor people and forms an important component of dryland agriculture. Sorghum is being a widely adaptive and drought resistant in nature, so it is often called as "crop camel."

It is inherently very efficient and fits well in the intercropping situation with legumes. Sorghum was mainly grown in kharif as well as Rabi seasons. Higher demand for food grain on account of alarmingly increasing 
population has consequently put as extra pressure on availability of cultivated land area per capita. Adequate food grain could only be produced from this meager area through intensification of cropping both in time and space dimensions.

In India, sorghum occupies an area about 9.9 $\mathrm{M}$ ha with total production of $8.0 \mathrm{Mt}$ with an average productivity of $808.1 \mathrm{~kg} / \mathrm{ha}$ (Anonymous, $2004^{\mathrm{a}}$ ). Among different states, Maharashtra has total area about $1.91 \mathrm{M}$ ha under sorghum with total production of 2.40 Mt and average productivity was $1256 \mathrm{~kg} / \mathrm{ha}$ (Anonymous, $2004^{\mathrm{b}}$ ).

Intercropping is a potential beneficial system of the crop production. Sorghum legume intercropping system is of an immense importance to the farmers of rainfed regions having limited resources. It has insurance against total crop failure during adverse weather conditions. The system helps in stabilizing yields, returns and also in stepping up the pulse and oilseed production. Pigeonpea, greengram, blackgram and soybean are important legume crops of the region and are mostly taken as intercrops in sorghum.

\section{Materials and Methods}

The present investigation "Influence of integrated nutrient management on growth, yield and economics of sorghum based legume intercropping systems" was conducted at the Farm of Department of Agronomy, Dr. PDKV, Akola during the year 2002-03. The experiment having twenty four treatments were laid out in split plot design with three replications on clayey soil having $\mathrm{pH}$ 7.8. It was low in total nitrogen $(0.046$ $\%)$, organic carbon $(0.40 \%)$, available nitrogen (225.72 kg/ha) and phosphorus $(23.12 \mathrm{~kg} / \mathrm{ha})$ and marginally high in available potassium (294.14 kg/ha). The experiment was carried out on the same site with same randomization in both the years of experimentation. The treatment details along with the symbols used are given in Table 1. Total rainfall received during crop season was $636.9 \mathrm{~mm}$ as against the normal $(779.2 \mathrm{~mm})$ which was deficient by $142.3 \mathrm{~mm}$ than the normal. The rains received during the month of June were sufficient to carry out the sowing of the crops. Hence, the sowing was carried out at the end of last week of June ( $28^{\text {th }}$ June). Certified seed for all crops were used. Marking of rows at an interval of $45 \mathrm{~cm}$ was done with marker. All the crops were drilled except pigeonpea and vegetables (Cowpea, Dolichos and clusterbean) which were dibbled at intra row spacing of $30 \mathrm{~cm}$. In sorghum based intercropping system, 2:1 row proportion was maintained. This included 67 per cent plant population of base crop (sorghum) and 33 per cent population of intercrops. The recommended dose of fertilizer was applied to sorghum in its sole crop stand. While in intercropping system, the fertilizers were applied on their proportionate stand basis. FYM and biofertilizer (Azotobacter and Rhizobium) were applied as per treatments. The rate of application of FYM was $5 \mathrm{t} / \mathrm{ha}$ and used before sowing. Azotobacter was use as seed treatment to sorghum and Rhizobium to intercrops. Biofertilizers were applied @ 250 $\mathrm{gm} / 10 \mathrm{~kg}$ of seed. The data were statistically analysed by 'Analysis of variance method (Panse and Sukhatme, 1967).

\section{Results and Discussion}

The results are presented in table 2 and 3

\section{Yield attributes and yields of sorghum}

\section{Effect of intercropping systems}

Sorghum+ pigeonpea intercropping system recorded significantly highest weight of 
earhead, grain yield per plant of sorghum over other treatments. Grain, straw and biological yield per hectare of sorghum were highest with sole sorghum which was significantly superior over other treatments.

Sorghum + Soybean intercropping system recorded maximum harvest index which was at par with sole sorghum and sorghum+ pigeonpea intercropping system. However test weight and bhoosa yield per hectare were non-significant. Such type of enhancement in the yield attributes of sorghum in association of companion crop of soybean was reported by Gode and Bobde (1993) and Dubey et al., (1995).

Increase in these yield parameters might be attributed to higher plant density per unit area in the treatment plots of sole sorghum. Similar results of greater values in grain, straw and biological yield per hectare were observed by Khistaria et al., (1996) and Pal et al., (1991) while studying sorghum based intercropping systems. Such type of favourable results of harvest index with sorghum based intercroppings was recording by Singh and Jadhav (2003).

\section{Effect of integrated nutrient management}

Application of $50 \%$ RDF with 5 t/ha FYM and biofertilizers recorded significantly highest weight of earhead, grain yield per plant, grain, straw and biological yield per hectare of sorghum over other treatments.

Application of RDF for respective crops recorded significantly higher harvest index which was on par with application of $75 \%$ RDF with 5 t/ha FYM and with application of $50 \%$ RDF with 5 t/ha FYM and biofertilizers. However, test weight and bhoosa yield per hectare of sorghum were non-significant. Increase in these attributes of sorghum might be ascribed to better availability of nutrient and moisture due to presence of nitrogen fixing bacteria and organic manure (FYM) leading to enhanced growth and yield attributes. Similar results were stated by Pushparaj et al., (1995) and Ghosh et al., (2003). The enhancement in the values of grain, straw and biological yield per hectare might be attributed to favourable influence on growth and yield attributes which might have finally reflected in yields of sorghum. Similar results were reported by Ponuswamy et al., (2002) and Ghosh et al., (2003).

\section{Effect of interactions}

Interaction effects were found to be not significant for all the characters.

\section{Sorghum grain equivalent yield, total grain productivity and economics of system}

\section{Effect of intercropping systems}

Sorghum+ pigeonpea intercropping system recorded significantly highest sorghum grain equivalent yield, gross monetary returns (GMR), net monetary returns (NMR) and B:C ratio over other treatments. However, Sorghum+ pigeonpea intercropping system and sole sorghum being par recorded maximum total grain productivity over other treatments.

The higher values of sorghum grain equivalent in Sorghum+ pigeonpea intercropping attributed to better yield recovery of sorghum, additional benefits of pigeonpea yield and its better market price. Similar results were reported by Ramteke et al., (1995) and Khistaria et al., (1996).

The higher values of GMR, NMR and B:C ratio with sorghum + pigeonpea intercropping are due to the optimum cost of cultivation, enhancement in the productivity and better remunerative market price to both the component crops. 
Table.1 Treatment details along with symbols used

\begin{tabular}{|l|c|}
\hline Treatment name & Symbol \\
\hline A) Main plot treatments (Intercropping systems) & \\
\hline Sole sorghum & $\mathbf{I}_{\mathbf{1}}$ \\
\hline Sorghum + Pigeon pea & $\mathbf{I}_{\mathbf{2}}$ \\
\hline Sorghum + Greengram & $\mathbf{I}_{\mathbf{3}}$ \\
\hline Sorghum + Blackgram & $\mathbf{I}_{\mathbf{4}}$ \\
\hline Sorghum + Soybean & $\mathbf{I}_{\mathbf{5}}$ \\
\hline Sorghum + Cowpea & $\mathbf{I}_{\mathbf{6}}$ \\
\hline Sorghum + Dolichos lablab & $\mathbf{I}_{\mathbf{7}}$ \\
\hline Sorghum + Clusterbean & $\mathbf{I}_{\mathbf{8}}$ \\
\hline B) Sub plot treatments (Integrated nutrient management) & \\
\hline i) Recommended dose of fertilizer of respective crops (RDF) & $\mathbf{F}_{\mathbf{1}}$ \\
\hline ii) $75 \%$ RDF + 5t/ha FYM & $\mathbf{F}_{\mathbf{2}}$ \\
\hline iii) $50 \%$ RDF + 5 t/ha of FYM + Biofertilizers & $\mathbf{F}_{\mathbf{3}}$ \\
\hline \multicolumn{1}{|c|}{ (Azotobacter and Rhizobium) } & \\
\hline
\end{tabular}

Table.2 Yield attributes and yield of sorghum as influenced by different treatments

\begin{tabular}{|c|c|c|c|c|c|c|c|c|}
\hline Treatments & $\begin{array}{c}\text { Wt. of } \\
\text { earhead } \\
(\mathrm{g})\end{array}$ & $\begin{array}{c}\text { Test } \\
\text { wt } \\
\text { (g) }\end{array}$ & $\begin{array}{c}\text { Grain yield } \\
\text { /plant } \\
\text { (g) }\end{array}$ & $\begin{array}{c}\text { Grain } \\
\text { yield } \\
\text { (q/ha) }\end{array}$ & $\begin{array}{c}\text { Straw } \\
\text { yield } \\
\text { (q /ha) }\end{array}$ & $\begin{array}{c}\text { Bhoosa } \\
\text { yield } \\
\text { (q/ha) }\end{array}$ & $\begin{array}{c}\text { Biologica } \\
\text { l yield } \\
\text { (q /ha) }\end{array}$ & $\begin{array}{c}\text { Harvest } \\
\text { Index } \\
(\%)\end{array}$ \\
\hline \multicolumn{9}{|l|}{ Intercropping systems } \\
\hline$I_{1}$-Sole sorghum & 36.33 & 20.07 & 25.42 & 48.14 & 109.91 & 14.24 & 172.29 & 27.96 \\
\hline $\mathbf{I}_{2}$-Sorghum + Pigeonpea & 43.73 & 20.89 & 31.00 & 42.47 & 98.43 & 12.28 & 153.18 & 27.78 \\
\hline $\mathbf{I}_{3}$ - Sorghum + Greengram & 34.84 & 19.95 & 24.47 & 35.68 & 91.36 & 11.94 & 138.99 & 25.67 \\
\hline $\mathbf{I}_{4}$ - Sorghum + Blackgram & 39.74 & 20.25 & 25.77 & 37.76 & 96.23 & 12.09 & 146.09 & 25.82 \\
\hline$I_{5}$-Sorghum + Soybean & 40.27 & 20.58 & 28.37 & 41.21 & 91.24 & 11.83 & 144.29 & 28.53 \\
\hline$I_{6}$-Sorghum + Cowpea & 31.28 & 19.89 & 21.83 & 33.02 & 83.51 & 11.75 & 128.28 & 25.84 \\
\hline $\mathbf{I}_{7^{-}}$Sorghum + Dolichos lablab & 30.77 & 19.80 & 21.02 & 32.72 & 82.07 & 10.81 & 125.60 & 26.08 \\
\hline $\mathbf{I}_{8^{-}}$Sorghum + Clusterbean & 29.53 & 19.58 & 20.74 & 32.45 & 86.38 & 11.12 & 129.95 & 25.04 \\
\hline $\mathrm{SE}(\mathrm{m}) \pm$ & 1.11 & 0.29 & 0.85 & 0.73 & 1.59 & 0.67 & 1.96 & 0.49 \\
\hline $\mathrm{CD}(\mathrm{P}=\mathbf{0 . 0 5})$ & 3.37 & NS & 2.59 & 2.22 & 4.83 & NS & 5.95 & 1.47 \\
\hline \multicolumn{9}{|l|}{ Integrated nutrient management } \\
\hline$F_{1}-\operatorname{RDF}($ Respective crop) & 32.96 & 19.79 & 22.67 & 35.83 & 84.39 & 11.50 & 131.72 & 27.13 \\
\hline $\mathrm{F}_{2}-75 \% \mathrm{RDF}+5$ t/ha FYM & 35.87 & 20.14 & 24.58 & 38.01 & 92.73 & 12.06 & 142.80 & 26.53 \\
\hline $\begin{array}{l}F_{3}-50 \% \text { RDF }+5 \text { t/ha FYM+ } \\
\text { Biofertilizers }\end{array}$ & 38.61 & 20.45 & 27.23 & 39.96 & 100.05 & 12.46 & 152.47 & 26.11 \\
\hline $\mathrm{SE}(\mathrm{m}) \pm$ & 0.88 & 0.19 & 0.57 & 0.43 & 0.78 & 0.37 & 0.97 & 0.25 \\
\hline $\mathrm{CD}(\mathrm{P}=\mathbf{0 . 0 5})$ & 2.53 & NS & 1.65 & 1.25 & 2.24 & NS & 2.79 & 0.73 \\
\hline \multicolumn{9}{|l|}{ Interaction (IxF) } \\
\hline $\mathrm{SE}(\mathrm{m}) \pm$ & 2.48 & 0.55 & 1.62 & 1.23 & 2.20 & 1.06 & 2.73 & 0.72 \\
\hline $\mathrm{CD}(\mathrm{P}=0.05)$ & NS & NS & NS & NS & NS & NS & NS & NS \\
\hline
\end{tabular}


Table.3 Sorghum grain equivalent (q/ha), total grain productivity $(\mathrm{q} / \mathrm{ha})$ and economics of sorghum based intercropping systems as influenced by different treatments

\begin{tabular}{|c|c|c|c|c|c|}
\hline Treatments & $\begin{array}{c}\text { Sorghum grain } \\
\text { equivalent } \\
\text { yield (q/ha) }\end{array}$ & $\begin{array}{l}\text { Total grain } \\
\text { productivity } \\
\text { (q/ha) }\end{array}$ & $\begin{array}{c}\text { GMR } \\
\text { (Rs./ha) }\end{array}$ & $\begin{array}{l}\text { NMR } \\
\text { (Rs./ha) }\end{array}$ & $\begin{array}{l}\mathrm{B}: \mathrm{C} \\
\text { ratio }\end{array}$ \\
\hline \multicolumn{6}{|l|}{ Intercropping systems } \\
\hline$I_{1}$-Sole sorghum & 48.14 & 48.14 & 41295 & 29196 & 3.42 \\
\hline $\mathbf{I}_{2}$-Sorghum + Pigeonpea & 66.88 & 48.98 & 49852 & 37946 & 4.20 \\
\hline $\mathbf{I}_{3}$ - Sorghum + Greengram & 44.35 & 37.96 & 36914 & 25180 & 3.16 \\
\hline$I_{4}$ - Sorghum + Blackgram & 49.46 & 41.02 & 40201 & 28546 & 3.45 \\
\hline I $_{5}$-Sorghum + Soybean & 51.68 & 44.42 & 40548 & 28363 & 3.33 \\
\hline$I_{6}-$ Sorghum + Cowpea & 51.38 & 43.58 & 38891 & 26209 & 3.07 \\
\hline I - Sorghum + Dolichos lablab & 43.46 & 38.89 & 34865 & 22420 & 2.81 \\
\hline I8- Sorghum + Clusterbean & 41.65 & 37.74 & 34901 & 21585 & 2.63 \\
\hline $\mathbf{S E}(\mathbf{m}) \pm$ & 0.86 & 0.75 & 451 & 451 & 0.04 \\
\hline $\mathrm{CD}(\mathrm{P}=\mathbf{0 . 0 5})$ & 2.62 & 2.26 & 1369 & 1369 & 0.11 \\
\hline \multicolumn{6}{|l|}{ Integrated nutrient management } \\
\hline$F_{1}-$ RDF(Respective crop) & 46.19 & 40.01 & 36693 & 25817 & 3.39 \\
\hline $\mathrm{F}_{2}-75 \% \mathrm{RDF}+5 \mathrm{t} / \mathrm{ha} \mathrm{FYM}$ & 49.73 & 42.67 & 39788 & 26646 & 3.04 \\
\hline $\begin{array}{l}\mathrm{F}_{3}-50 \% \mathrm{RDF}+5 \mathrm{t} / \mathrm{ha} \text { FYM+ } \\
\text { Biofertilizers }\end{array}$ & 52.96 & 45.10 & 42570 & 29829 & 3.35 \\
\hline $\mathbf{S E}(\mathbf{m}) \pm$ & 0.50 & 0.44 & 263 & 263 & 0.02 \\
\hline $\mathrm{CD}(\mathrm{P}=\mathbf{0 . 0 5})$ & 1.43 & 1.26 & 758 & 758 & 0.06 \\
\hline \multicolumn{6}{|l|}{ Interactions (IxF) } \\
\hline $\mathbf{S E}(\mathbf{m}) \pm$ & 1.40 & 1.24 & 744 & 744 & 0.06 \\
\hline $\mathrm{CD}(\mathrm{P}=\mathbf{0 . 0 5})$ & NS & NS & NS & NS & NS \\
\hline
\end{tabular}

These results coincide with the findings of Narkhede et al., (1992) and Kushwaha and Kushwaha (1995). Increased values of total grain productivity might be ascribed to better performance of these treatments for base crop as well as intercrops. Such results were documented by Dhope et al., (1992) and Mahakulkar et al., (1995).

\section{Effect of integrated nutrient management}

Application of $50 \%$ RDF with 5 t/ha FYM and biofertilizers recorded significantly highest sorghum grain equivalent yield, total grain productivity, gross monetary returns (GMR) and net monetary returns (NMR) over other treatments. However, B:C ratio was maximum with application of RDF for respective crops (F1) and application of $50 \%$ RDF with 5 t/ha FYM and biofertilizers (F3) .

The higher values of sorghum grain equivalent might be due to better performance of FYM and biofertilizer with inorganic fertilizers to increased crop yields. Results are in conformity with results reported in the past years (Anonymous, 1998). The higher monetary returns (GMR and NMR) might be due to higher productivity of base and component crops and optimum cost of cultivation. Similar result was reported by Anonymous, 1998. B:C ratio results are in line with the findings of Balasubramanian et al., (1995). 


\section{Effect of interactions}

Interaction effects were found to be not significant.

\section{References}

Anonymous (1998). Integrated nutrient management in sorghum based cropping systems. Progress Report, AICSIP, Hyderabad : SA 10 - SA 19.

Anonymous $\left(2004^{\mathrm{a}}\right)$. Area and production of primary crops. FAO website http:// faostat.fao.org. / faostat / collections.

Anonymous $\left(2004^{\mathrm{b}}\right)$.District wise area, production and productivity of field crops. Govt. of Maharashtra website http: // agri.mah.nic.in. / statistics / agricultural statistics/.

Balasubramanian, A., K. Ramamoorthy and S. Purushothaman (1995). Influence of fodder and grain legumes and enriched FYM on nutrient management of rainfed sorghum. Indian J. Dryland Agric. Res. \& Dev. 10(2) : 193-198.

Dhope, A.M., B.V. Mahakulkar, S.S. Wanjari, V.B. Shekar and N.R. Potdukhe (1992). Intercropping at leguminous crops in newly evolved sorghum genotype (SPV 669). Crop Res. 5(2) : 207-211.

Dubey, D.N., G.S. Kulmi and Girish Jha $\left(1995^{\mathrm{a}}\right)$. Performance of sorghum (Sorghum bicolor) as influenced by intercropping and planting geometry. Indian J. Agron. 40(3) : 353-356.

Ghosh, P.K., K.K. Bandopadhyay, A.K. Tripathi, K.M. Hati, K.G. Mandal and A.K. Mishra (2003). Effect of integrated management of farm yard manure, phosphocompost, poultry manure and inorganic fertilizers for rainfed sorghum (Sorghum bicolor) in Vertisols of India. Indian J. Agron. 48(1) : 48-52.

Gode, D.B. and G.N. Bobde (1993). Intercropping of soybean in sorghum. PKV Res. J. 17(2):128-129

Khistaria, M. K., M. G. Khokhani and D.R. Padmani (1996). Intercropping of important pulses and oilseeds in sorghum under rainfed conditions. J. Maharashtra Agric. Univ. 21(3) : 388-390.

Kushwaha, S.S. and B.B. Kushwaha (1995). Studies on fertilizer management in sorghum based cropping systems. Crop Res. 10(2) : 63-66.

Mahakulkar, B.V., S.S. Wanjari, N.R. Potdukhe, V.B. Shekar and R.W. Ingle (1995). Productivity of newly evolved sorghum (sorghum bicolor) genotypes based intercropping systems. Indian $J$. Agron. 40(2) :169-171.

Narkhede, W.N., P.N., Nandurkar, S.L. Jadhao and S.K. Kohale (1992). Effect of intercropping of legumes in rainfed sorghum on yield and economics. $P K V$ Res. J. 16(1) : 13-17.

Pal, M.S., P.C. Gupta and O. P. Singh (1991). Effect of sorghum based intercropping systems on productivity, land equivalent ratio and economics in Mollisols of Nainital Tarai (U.P.) Indian J. Agron. 36(1) : 12-16.

Panse, V.G. and P.V. Sukhatme (1967). Statistical methods for agricultural workers, ICAR, New Delhi.

Ponnuswamy, K., P. Subbian, P. Santhi and N. Sankaran (2002). Integrated nutrient management for rainfed sorghum. Crop Res. 23(2) :243-246.

Pushparaj, G., G.S. Thangamuthu, M.R. Iruthayaraj and D. Purushothaman (1995). Yield attributes and yield of $\mathrm{N}$ and Rhizobium inoculations in sorghum soybean intercropping. Madras Agric. J. 82(2) : 112-114.

Ramteke, C.N., K. T. Nagre, S.B. Bhoyte and N.D. Parlawar (1995). Effect of intercropping of sorghum with legume and oil seeds on yield and economics. PKV Res. J. 19(1) : 62-64.

Singh, P. K. and A. S. Jadhav (2003). Intercropping of sorghum with pigeonpea, groundnut and soybean under varying planting geometry. Indian $J$. Dryland Agric. Res. \& Dev. 18(2) : 126-129. 


\section{How to cite this article:}

Bhagat. G. J., D. G. Giri, P. C. Pagar and Hadole. S. S. 2020. Effect of Integrated Nutrient Management on Yield Attributes, Yield and Economics of Sorghum Based Intercropping Systems. Int.J.Curr.Microbiol.App.Sci. 9(06): 563-569.

doi: https://doi.org/10.20546/ijcmas.2020.906.073 